\title{
CASE STUDY: POLICIES, STRATEGIES AND RESPONSES TO PLAGIARISM IN SLOVAKIA
}

\author{
Tomas Foltynek $^{1}$, Julius Kravjar ${ }^{2}$, Irene Glendinning ${ }^{3}$ \\ ${ }^{1}$ Mendel University in Brno, ${ }^{2}$ Centre of Scientific and Technical Information, ${ }^{3}$ Coventry University
}

\author{
Highlights \\ - $\quad$ The case study describes the situation about plagiarism in Slovakia
}

\begin{abstract}
The European project "Impact of Policies for Plagiarism in Higher Education Across Europe" has identified best practices and gaps related to plagiarism in different European countries. Slovakia is one of the interesting ones, where national repository for plagiarism detection was established. However, there are still gaps in terms of policies and overall understanding of plagiarism. This case study describes what happened in Slovakia in last few years, compares the situation with other European countries and discusses the results. Additionally, the number of occurrences of the terms "plagiarism", "academic ethics" and "academic integrity" in media and on the Internet is examined in relation to recent changes.
\end{abstract}

\section{Keywords}

Plagiarism policies, Slovakia, National repository
Article type

Short Communication

Article history

Received: January 16, 2014

Received in revised form: March 21, 2014

Accepted: March 24, 2014

Available on-line: March 31, 2014

Foltýnek, T. et al. (2014) "Case Study: Policies, Strategies and Responses to Plagiarism in Slovakia", Journal on Efficiency and Responsibility in Education and Science, Vol. 7, No. 1, pp. 19-25, online ISSN 1803-1617, printed ISSN 2336-2375, doi: 10.7160/eriesj.2014.070104.

\section{Introduction and Motivation}

The project Impact of Plagiarism in Higher Education Accross Europe (IPPHEAE) was funded by the European Union's LLP/Erasmus Programme and took part from 2010 to 2013. The project's goal was to find out how the growing problem of plagiarism is being addressed in different EU countries. As a result, a report for each particular country was issued. Situation in Slovakia is quite outstanding and brings valuable experience worth sharing with other countries. That is why we decided to publish this case study. The goal of this case study is to describe changes in Slovakia, evaluate differences between Slovakia and the rest of Europe and point out some interesting facts coming from Slovakia's experience. We will talk namely about differences between software tools for plagiarism detection, plagiarism policies and penalties for plagiarism. These concepts are often not distinguished properly, which may lead to problems.

Although a much research has been conducted in the UK (Borg, 2009) and parts of Europe (Pecorari, Shaw, 2012) into policies for plagiarism and aspects of academic dishonesty and cultural differences (Leask, Carroll, 2011), this is the first time an EUwide survey has been completed on this subject. The IPPHEAE research design was influenced by much of the earlier research in Europe (Carroll, 2007) and (Weber-Wulff, Wohnsdorf, 2006), Australia (Bretag, Mahmud, 2009) and USA (McCabe, 2005).

\section{Background Information}

This part of the study was previously published at (Kravjar, Noge, 2013).

Low awareness of copyright, intellectual property rights and academic ethics combined with a growing number of Internet users, students and higher education institutions have created a breeding ground for the spread of plagiarism in written papers in Higher Education Institutions. According to (Skalka, Drlík and
Vozár, 2009) 'Internet was the likely catalyst for an avalanche of plagiarism; it provided students, often including primary school pupils, with resources for quick, easy and effortless access to information about the assigned topic and later even complete texts.

A comprehensive overview of the state of academic ethics in Slovakia is analysed by Králiková (2009) in her publication "Implementation of rules of academic ethics at Slovak HEIs". She states that: 'The issue of academic ethics started to attract attention in Slovakia especially in the past three years. It usually appeared in relation to the issue of plagiarism among students and teachers. However, plagiarism is just one of the infractions against academic ethics and the issue of academic ethics in Slovakia is much broader than just plagiarism. '

Staroňová (2010) described the causes supporting plagiarism as follows: '...plagiarism has its roots mainly in the method of teaching; the absence of systematic education (ideally from the primary school level), teaching the students to write argumentative texts, list resources correctly, benefits of quotations (it is much easier to go back to the original source and critically consider the author's conclusions) and especially ethical principles that would clearly define plagiarism as violation of intellectual property rights and parasitizing on the work of others and not playing down the situation. It is very sad to watch how many teachers who should teach students ethical principles, explain to them the nature of plagiarism and require them to think and write originally are themselves guilty of the sin and play down its significance if caught in the act.

In 1989, there were 13 HEIs in Slovakia and today there are 40; 36 operate under the Slovak legal order. The development of the number of students, teachers, HEIs (iEDU, 2012) and the number of Internet users (www.indexmundi.com, 2012) is shown in Graph 1. The number of students and teachers apply to HEIs operating under the Slovak legal order. 
The year 2000 saw the highest annual increase in the number of HEIs (5), 2002 was the year with the highest increase in the number of Internet users (nearly 1.5 million, almost $28 \%$ of the total population). In 2006, there was the highest annual increase in the number of students (over 20,000); 2004 and 2005 were also the years of high annual increases in the number of students (more than 17,000 and more than 18,000 respectively). The highest increase in the number of teachers (774) was recorded in 2009 .

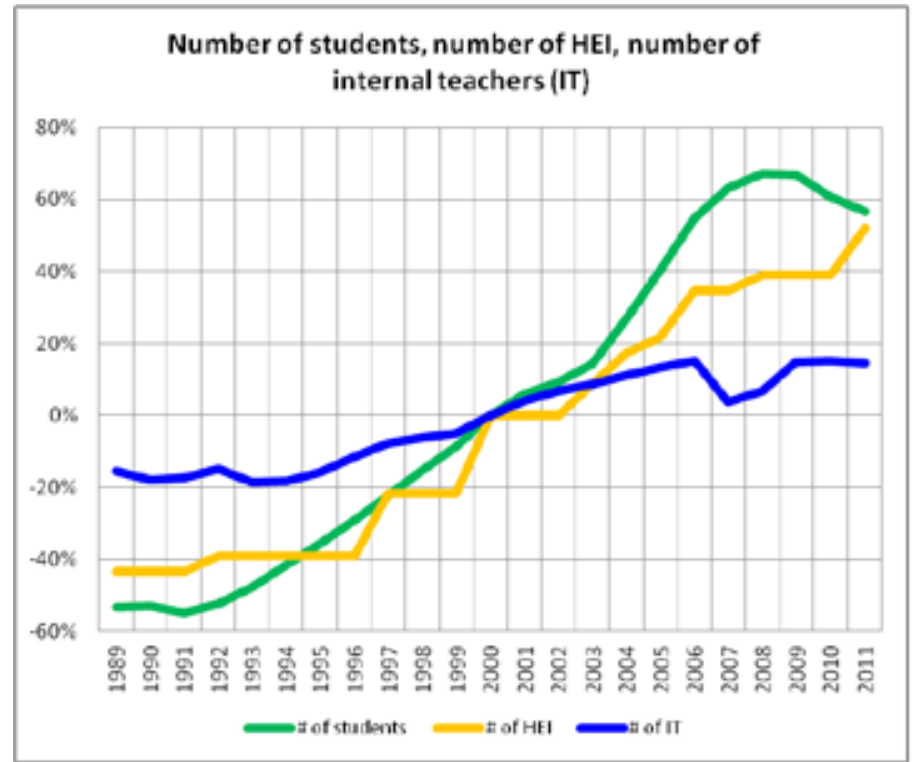

In 2006, more than 213,000 students studied at Slovak HEIs for-3.3 times the number in 1989; by that year the HE sector had expanded to 32 HEIs - 2.4 times the number in 1989; the number of internet users increased and exceeded 3 million, representing more than $55 \%$ of the total population. However, still only one HEI used an electronic system to detect plagiarism. In 2008, another HEI (University of Economics in Bratislava) implemented detection software and in 2009 by a third HEI (Comenius University in Bratislava) had followed their lead.

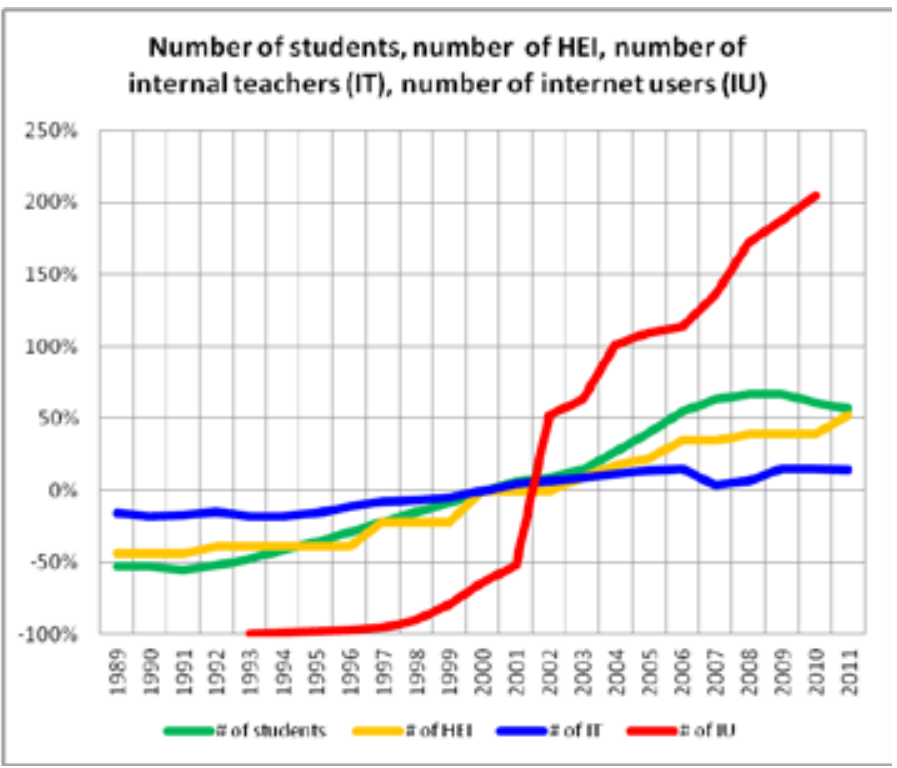

Graph 1: Development of observed indicators over time transformed according to the formula $100 *\left(x_{i}-x_{\text {median }}\right) / x_{\text {median }}$ (Kravjar, Noge, 2013)

At the time of writing this case study, there are 20 public, 3 state and 13 private HEIs in Slovakia. According to the Annual report on the state of higher education in Slovakia (Ministry of Education, 2012), there are currently approx. 200,000 students. Almost $5 \%$ of them are from foreign countries, mainly from Greece, Norway and the Czech Republic. Around $60 \%$ of students study in bachelor degree, $30 \%$ in following master's degree, $5 \%$ in "long" masters degree and $5 \%$ in $\mathrm{Ph} . \mathrm{D}$. degree. From the population of 19 years olds $57.7 \%$ enter Higher Education. The most popular fields of study are social sciences (including economics) (58\% of students), followed by technical sciences $(20 \%)$, health sciences $(9 \%)$ and natural sciences (5\%). Total public income for all (public) Slovak HEIs was approximately 450 million EUR. More than 2000 students (1\%) realized their international mobility in 2012. The most popular destinations are the Czech Republic, Germany and Spain. More than 1100 international students chose Slovakia as their destination increasing the Slovak student population by $0.6 \%$.

\section{Introducing the Plagiarism Detection Software}

This part of the study draws significant inspiration from (Kravjar, Noge, 2013) and (Kravjar, 2013).

In Slovakia, there were many discussions on the subject of plagiarism, but without a specific result for a long time. In 2001, the first HEI (Vysoká škola manažmentu-in Trenčín) in Slovakia started to use an electronic system to detect plagiarism. The system to detect plagiarism was not the only innovation in this HEI; there were also other related measures: the rules of academic ethics were adopted, as well as a process defining the procedure for the investigation of suspected plagiarism (Kročitý, Argaláš, 2010).
Initially opinions of representatives of HEIs varied greatly on the use of the system to detect plagiarism. The Slovak Rectors' Conference (SRC) plenary's opinion on plagiarism dated 28 September 2006 entitled "Measures to eliminate plagiarism in the processing and presentation of bachelor's, master's and dissertation theses" (Slovak Rectors' Conference, 2006a) was a significant event for promoting changes in perceptions about the use of software. The document is important because it states that:

- Plagiarism is considered a serious problem that must be addressed by informing students how to write papers correctly and how to cite literary sources;

- The best way to reduce plagiarism is prevention;

- In the case of confirmed plagiarism, it requires that the student bears the consequences in accordance with the internal regulations of a HEI.

Another important document was approved by SRC on the same day, "The Code of Ethics for HEI Employees" (Slovak Rectors' Conference, 2006b). However, the Code contains no mention of plagiarism, as if plagiarism had no relationship to teaching and research staff of HEIs.

These two documents did not change the status quo nor did they affect the suppression of plagiarism. A more effective action was needed, with a major impact on combating plagiarism. SRC (February, 2008) adopted a resolution with the potential for a fundamental solution. The plenary of Slovak Rectors' Conference revisited the issue of plagiarism. It asked the Ministry of Education of the Slovak Republic to coordinate the relevant activities, especially those relating to the acquisition of the software. It also urged the members of the Slovak Rectors' Conference to create an electronic archive of theses. 
It recommended that HEIs modified their regulations to address the issue of plagiarism.

In March 2008, Internet media reported (Supuka, 2008) that the Minister of Education promised to obtain software to control plagiarism for HEIs in Slovakia،. The Ministry of Education decided that a comprehensive solution would be implemented at a national level covering the collection, processing and originality check of specified papers. HEIs in Slovakia would be required to use this comprehensive solution (Skalka et al., 2009). repository and system to detect plagiarism began on 30 April 2010.

The launch of central repository along with plagiarism detection system into live operation represents a significant milestone in the fight against plagiarism of theses and dissertations (bachelor's, master's, rigorous, dissertation, habilitation) at HEIs in Slovakia. The pre-implementation period and the first months of the operation of these systems was a period when plagiarism often appeared in the media and on the Internet. When we consider the time interval from 2002 to 2010 the

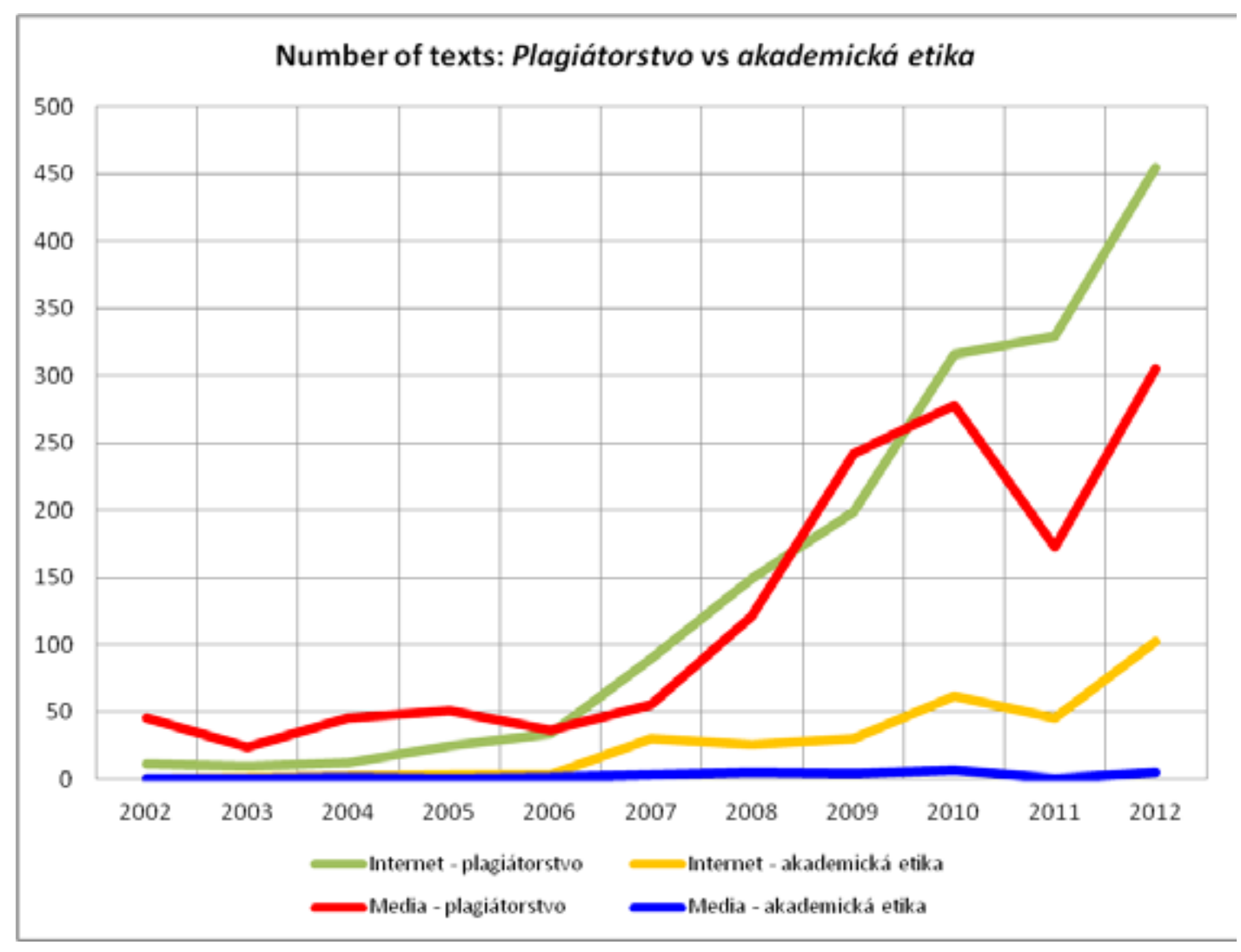

Graph 2: The number of text occurrences concerning plagiátorstvo and akademická etika on the Internet and in the media (Kravjar, 2013)

The basic strategic goal was defined and it was necessary to develop a strategy to achieve it. One of the major factors that contributed to the success in achieving the strategic objective was finding the support in the Parliament and incorporation in the amendment to the Higher Education Act of the obligations for HEIs to send specified papers in the central repository in order to be checked for originality after registration.

The amendment to the Higher Education Act was approved in 2009 and paved the way for the preparation of a nationwide repository of bachelor, master, dissertation, rigorous ${ }^{1}$ and habilitation $^{2}$ theses. Slovak Centre of Scientific and Technical Information (SCSTI) was commissioned by the Ministry of Education to define system requirements definition, obtain the necessary software by public procurement, to implement it and SCSTI was also made responsible for its operation and further development. The preparation phase was challenging because of the perceived urgency. The real operation of the central 1 A "small doctorate" can be received by a person with a master's degree. It requires that a candidate passes rigorous examination and defends his/her rigorous thesis.

2 A prerequisite for the granting of the scientific-pedagogical degree "docent" (assistant professor) is habilitation lecture, submission and defence of the habilitation thesis. number of texts containing the word plagiátorstvo and all of its forms on the Internet and in the media reached maximum just in the year 2010. The expectation, that the significant growth will be present too in the case of terms academic ethics and academic integrity, it was not confirmed (Graph 2). The maximum of texts containing the term akademická etika including all its forms for the 2002-2010 is reached in 2010 for Internet and for media. But the frequency of term akademická etika on Internet is many times lower than the frequency of the term plagiátorstvo, it amounts to $15.6 \%$ on average. The occurrence of texts containing the term akademická etika is low - 26 total occurrences with peak value 7 in 2010. In the case of akademická integrita, the occurrence of the term was even lower than in the case of academic ethics. On the Internet, we found 12 texts with a maximum of 5 in 2011. In the media, there was no occurrence of the term akademická integrita and that is something that was not assumed at all.

The occurrence of texts about akademická etika and akademická integrita shows that these terms are infrequent in the text on Internet and in the media and it is likely that knowledge of these terms, their meaning and understanding in the society is low. It is a negative situation that requires action. Why? Because full understanding and respecting of academic ethics and academic integrity can significantly contribute to the prevention of plagiarism. 


\section{Comparison of Slovakia with the EU average}

This part of the study draws significant inspiration from (Foltýnek, 2013).

On analysis of student responses to the survey of HEIs conducted for the IPPHEAE project, several notable differences were found and reported between the Slovak responses and the EU averages. We have examined almost 5000 anonymous surveys from all EU countries, 236 of them were from Slovakia. Respondents were students and teachers from several different HEIs.

Almost all Slovak students (99\%!) become aware of plagiarism before or during their bachelor studies. The EU average shows that $20 \%$ of students become aware of plagiarism during their gave us following results:

Also the other sub-questions of this question provided results proving that Slovak students are the most aware of plagiarism among all EU countries.

\section{Reasons for students' plagiarism}

This part of the study draws significant inspiration from (Foltýnek, 2013).

Slovak students think that the most important reasons leading students to plagiarism are easiness of cutting and pasting from the Internet, students' convincement that they would not be caught, running out of time and the fact, that students do not want to learn anything, just pass the assignment. These reasons

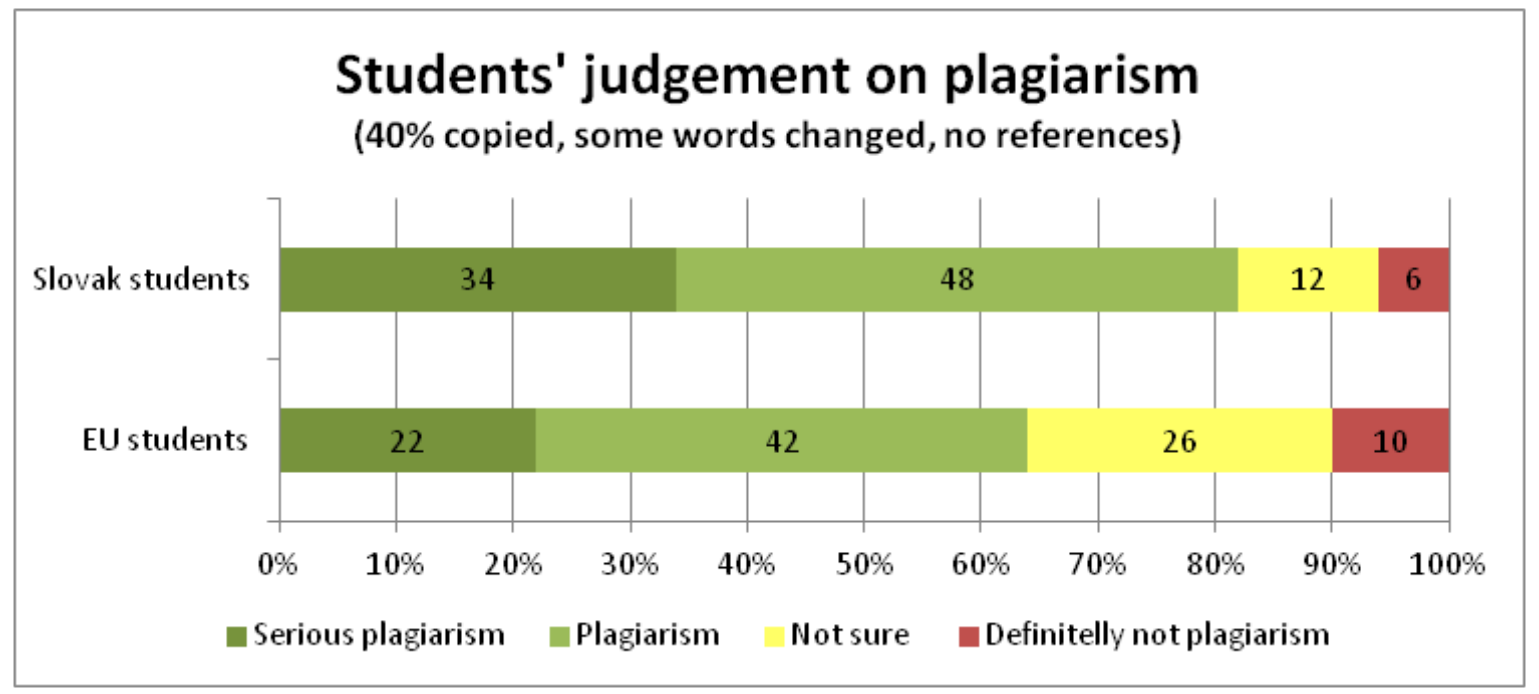

Graph 4: Students' judgement on plagiarism (IPPHEAE survey results)

masters/PhD degree or are still not sure about it. Although the percentage of students receiving training in scholarly academic writing was similar (62\% in SK compared to $60 \%$ in EU), Slovak students were much less likely to ask for more training in plagiarism, academic writing and academic integrity (36\% in SK compared to $63 \%$ for all EU). Significant numbers of Slovak students $(96 \%)$ were convinced that their institution had policies and procedures for dealing with plagiarism. The EU average for this criterion is $66 \%$. Students were convinced that policies were available to students ( $80 \%$ in SK, $53 \%$ in EU), that penalties were administered according to a standard formula ( $62 \%$ in SK, $38 \%$ in EU). They were also convinced about the existence of policies dealing with academic dishonesty $(87 \%$ in SK, $56 \%$ in EU). Evidence that indicated Slovak universities do address this problem was the fact that $70 \%$ of students correctly identified a case of serious plagiarism from a scenario that only $37 \%$ of EU-wide student respondents were able to identify. The percentage of Slovak students thinking that one of their teachers may have plagiarized in his/her class notes was almost the same as that for the EU as a whole (33\% in SK, $30 \%$ in EU). Only $14 \%$ of Slovak students said they might have plagiarized, whereas the average for all EU student responses was $29 \%$.

The most frequent methods for Slovak students to get to know about plagiarism are student guides and handbooks followed by workshops.

When given a specific case ( $40 \%$ of a student's submission is from other sources and is copied into the student's work), Slovak students were more likely to judge it as plagiarism (or serious plagiarism), compared to the EU average. For example, the subquestion stating that some words in copied $40 \%$ of text were changed, but with no quotations, references or in text citations, are also the most important ones for all EU students.

If we highlight reasons, where Slovak answers differ from EU ones by more than 10 per cent points, we can see interesting results (see table below). We can see that the biggest differences are in these reasons:

- They are not aware of penalties

- They think their written work is not good enough

- They can't express another person's ideas in their own words

- There is no teachers control on plagiarism

- They don't understand how to cite and reference

- The consequences of plagiarism are not understood

Slovak students tend to underscore all of these criteria compared to EU students. We can see that the introduction of the central plagiarism detection tool led to the knowledge that there are penalties, there is teachers control on plagiarism and the consequences are understood. The other reasons (their written work is not good enough, they can't express another person's ideas in their own words and they don't understand how to cite and reference) show other differences in Slovak attitudes, which are probably not related to the existence of central repository.

We can see that the only reason significantly over-scored by Slovak students was that they are unable to cope with the workload.

Another reason, mentioned by some students, is diversity of assignments. Teachers usually give the same assignment to all of the students, or the assignment is the same as it was in previous years. Very often the assignment does not support enough variety, so students know that their texts will be similar to each 
other anyway. In this situation it is practically impossible to avoid plagiarism and students naturally tend to copy their work.

\section{Penalties for plagiarism}

This part of the study draws significant inspiration from (Foltýnek, 2013).

We have examined what happen if a case of plagiarism is uncovered. It is often up to the teacher to decide. Where the case is more severe (depends on the teacher's opinion), the student is sent to the disciplinary committee. The most common penalty is zero mark and repetition or failure of the module or subject.
In case of plagiarised dissertation, student is likely to be expelled from the institution. The students often added comments, that a specific penalty depends on the scale of plagiarized text and on whether it is student's first case of plagiarism or not.

If we compare Slovak students' answers with the EU average, we can see that Slovaks underscore less severe criteria (no action would be taken, verbal warning) and are more likely to tick the more severe criteria (repeat or fail the module or subject, suspend from the institution). This proves that Slovak students are more convinced than their European colleagues, that the consequences of plagiarism are severe.

\begin{tabular}{|l|l|l|l|}
\hline & Reason & $\begin{array}{l}\text { SK } \\
\text { students }\end{array}$ & $\begin{array}{l}\text { EU } \\
\text { students }\end{array}$ \\
\hline 1 & They think the lecturer will not care: & $33 \%$ & $31 \%$ \\
\hline 2 & They think they will not get caught: & $63 \%$ & $62 \%$ \\
\hline 3 & They run out of time: & $71 \%$ & $64 \%$ \\
\hline 4 & They don't want to learn anything, just pass the assignment: & $63 \%$ & $53 \%$ \\
\hline 5 & They don't see the difference between group work and collusion: & $9 \%$ & $16 \%$ \\
\hline 6 & They can't express another person's ideas in their own words: & $42 \%$ & $55 \%$ \\
\hline 7 & They don't understand how to cite and reference: & $41 \%$ & $52 \%$ \\
\hline 8 & They are not aware of penalties: & $19 \%$ & $41 \%$ \\
\hline 9 & They are unable to cope with the workload: & $53 \%$ & $41 \%$ \\
\hline 10 & They think their written work is not good enough: & $\mathbf{1 5 \%}$ & $\mathbf{3 3 \%}$ \\
\hline 11 & They feel the task is completely beyond their ability: & $30 \%$ & $28 \%$ \\
\hline 12 & It is easy to cut and paste from the Internet: & $66 \%$ & $67 \%$ \\
\hline 13 & They feel external pressure to succeed: & $16 \%$ & $25 \%$ \\
\hline 14 & Plagiarism is not seen as wrong: & $34 \%$ & $35 \%$ \\
\hline 15 & They have always written like that: & $32 \%$ & $34 \%$ \\
\hline 16 & Unclear criteria and expectations for assignments: & $17 \%$ & $22 \%$ \\
\hline 17 & Their reading comprehension skills are weak: & $23 \%$ & $27 \%$ \\
\hline 18 & Assignments tasks are too difficult or not understood: & $25 \%$ & $25 \%$ \\
\hline 19 & There is no teachers control on plagiarism: & $\mathbf{8 \%} \%$ & $\mathbf{2 0 \%}$ \\
\hline 20 & There is no faculty control on plagiarism: & $88 \%$ & $39 \%$ \\
\hline 21 & The consequences of plagiarism are not understood: & $14 \%$ \\
\hline
\end{tabular}

Table 1: Reasons leading students to plagiarism (IPPHEAE survey results)

\begin{tabular}{|l|l|r|r|r|r|r|}
\hline & & \multicolumn{2}{|c|}{ SK Students } & & \multicolumn{2}{|c|}{ EU Students } \\
\hline & & Assign. & \multicolumn{1}{|c|}{ Dissert. } & & Assign. & Dissert. \\
\hline a. & No action would be taken & $4 \%$ & $0 \%$ & $<<$ & $21 \%$ & $5 \%$ \\
\hline b. & Verbal warning & $26 \%$ & $7 \%$ & $<<$ & $50 \%$ & $15 \%$ \\
\hline c. & Formal warning letter & $26 \%$ & $14 \%$ & $=<$ & $27 \%$ & $26 \%$ \\
\hline d. & Request to rewrite it properly & $29 \%$ & $16 \%$ & $<<$ & $51 \%$ & $35 \%$ \\
\hline e. & Zero mark for the work & $68 \%$ & $44 \%$ & $>=$ & $53 \%$ & $42 \%$ \\
\hline f. & Repeat the module or subject & $64 \%$ & $38 \%$ & $>>$ & $38 \%$ & $26 \%$ \\
\hline g. & Fail the module or subject & $46 \%$ & $38 \%$ & $>>$ & $38 \%$ & $26 \%$ \\
\hline h. & Repeat the whole year of study & $13 \%$ & $20 \%$ & $==$ & $11 \%$ & $19 \%$ \\
\hline i. & Fail the whole programme or degree & $24 \%$ & $29 \%$ & $>=$ & $13 \%$ & $33 \%$ \\
\hline j. & Expose the student to school community & $17 \%$ & $18 \%$ & $==$ & $14 \%$ & $19 \%$ \\
\hline k. & Suspended from the institution & $28 \%$ & $42 \%$ & $>>$ & $14 \%$ & $29 \%$ \\
\hline l. & Expelled from the institution & $24 \%$ & $34 \%$ & $>=$ & $12 \%$ & $30 \%$ \\
\hline m. & Suspend payment of student grant & $13 \%$ & $17 \%$ & $==$ & $13 \%$ & $19 \%$ \\
\hline n. & Other & $6 \%$ & $6 \%$ & $<<$ & $11 \%$ & $10 \%$ \\
\hline
\end{tabular}

Table 2: What happens when plagiarism is uncovered (IPPHEAE survey results) 


\section{Software versus Policies}

This part of the study draws significant inspiration from (Foltýnek, 2013).

We can see that the introduction of plagiarism detection software and the occurrence of the terms "plagiarism" and "academic integrity" in the media and on the Internet led to the students' convincement about the existence of unified guidelines.

However, if we look at the survey answers from 2 senior management staff at the same university, they will show us there are no unified guidelines for addressing plagiarism. Each of them was from different faculty and their answers were totally opposite. They both agreed that policies for plagiarism and other forms of academic dishonesty were separately defined. One of them added, ,Just the penalties are not known in case of top politicians'. However, answers to following questions seem like an exercise of negation: Do you think it should be [separately defined]? Yes. No. Do you have a set of standard penalties for cases of student plagiarism? No. Yes. Are there standard penalties for other forms of academic dishonesty? Are these penalties separate from those for plagiarism? No. Yes. Do the plagiarism policies, procedures and penalties differ according to a student's level or background? Yes. No. Are there other factors taken into account, e.g. first offences, international students, mitigation circumstances? Yes. No. And so on. When one looks at the methodical instructions for theses at this university, $\mathrm{s} / \mathrm{he}$ may find two mentions of plagiarism: , Thesis must not have the character of plagiarism and violate someone else's copyright. ' and: , The head of supervising department is to inform the dean of any case of plagiarism: According to study regulations, dean then passes the case to the disciplinary committee, which decides. And evidently, the result may be different from faculty to faculty. So the question is, can we consider these two mentions of plagiarism consider as "defined policy"?

\section{Conclusion}

Even though Slovakia has two key documents approved by the Slovak Rectors Conference, which introduce Ethical Codex, Measures to eliminate plagiarism and plagiarism detection software in operation, it does not mean unification of policies and procedures for dealing with plagiarism. However, the rising occurrence of the words "plagiarism", "academic ethics" and "academic integrity" raised public discussion about these topics and students are convinced that policies exist and probably think twice before committing plagiarism. Undoubtedly, it was significant step forward and Slovakia is much ahead of many European countries now, which was proved by the survey conducted under the IPPHEAE project. We have confirmed that Slovak students are much better informed about the concept of plagiarism than their European colleagues. The reasons possibly leading Slovak students to plagiarism are also significantly different from the EU average.

\section{Acknowledgements}

The research was funded by the project Impact of Policies for Plagiarism in Higher Education Across Europe (510321-LLP-12010-1-UK-ERASMUS-EMHE).

\section{References}

Borg, E. (2009). Local Plagiarisms. Assessment and Evaluation of Higher Education 34 (4), 415-426

Bretag, T., Mahmud, S. (2009). Self-plagiarism or appropriate textual re-use?. Journal of Academic Ethics. Vol. 7, Issue 3, September 2009, Pages 193-205

Carroll, J. (2007). Plagiarism as a Threat to Learning: An Educational Response. Joughin, G: Assessment, learning and judgement in higher education. ISBN: 978-1-4020-8904-6

Foltýnek, T. (2013). Plagiarism policies in Slovakia. Report. [Online] Available at: http://ippheae.eu/images/ results/2013_12_pdf/D2-3-26\%20SK\%20IPPHEAE\%20 MENDELU\%20Survey\%20SlovakiaNarrative\%20FINAL.pdf [12 Mar 2014]

iEDU (2012). Časové rady. [Online] Available at: http://www. uips.sk/statistiky/casove-rady. [15 Dec 2012].

Králiková, R. (2009): Zavádzanie pravidiel akademickej etiky na slovenských vysokých školách. Slovak governance institute. [Online] Available at: http://www.governance.sk/assets/files/ publikacie/akademicka_etika.pdf [12 Mar 2014]

Kravjar J. (2013). The Occurrence of the Terms akademická etika and akademická integrita in Texts on the Internet and in the Media. [Online] Available at: https://www.vedatechnika.sk/ Blog/Lists/Posts/Post.aspx?ID=89 [12 Mar 2014]

Kravjar J., Noge J. (2013). Strategies and responses to plagiarism in Slovakia. PLAGIARISM ACROSS EUROPE AND BEYOND - Conference Proceedings, pp. 201-215 [Online] Available at: http://ippheae.pefka.mendelu.cz/files/ proceedings.pdf [12 Mar 2014]

Kročitý P., Argaláš M. (2010). 10-ročné skúsenosti s bojom proti plagiátorstvu na Vysokej škole manažmentu $v$ Trenčine. [Online] Available at: http://www.apvv.sk/buxus/docs/aktuality/ konferencia-etika/konferencia-20100414-krocity-argalas.pdf. [21 Jan 2013].

Leask, B., Carroll, J. (2011). Moving beyond 'wishing and hoping': internationalisation and student experiences of inclusion and engagement. Higher education research \& development, Vol. 30, Issue: 5, Pages: 647-659, DOI: $10.1080 / 07294360.2011 .598454$

McCabe, D.L. (2005). Cheating amongst college students: A North American Perspective. International Journal for Academic Integrity 1(1) Available at: http://ojs.ml.unisa.edu.au/index.php/ IJEI/article/viewFile/14/9 [26 Mar 12].

Ministry of Education (2012): Annual report on the state of higher education in Slovakia in 2012. [Online] Available at http://www.minedu.sk/data/att/5183.zip [15 Sep 2013]

Pecorari, D., Shaw, D., (2012) Types of student Intertextuality and Faculty attitudes, Journal of Second Language Writing 21 (2012) 149-164 Elsevier

Skalka J., Drlík M., Grman J., Vozár L. (2009). Záverečné práce a plagiátorstvo. [Online] Available at: http://www.fem.uniag. sk/uninfos2009/sites/sk.uninfos2009/files/skalka.pdf. [24 Jan 2013].

Skalka J., Drlík M., Vozár L. (2009). Korene plagiátorstva. [Online] Available at: http://www.fem.uniag.sk/sit2009/ zbornik/13_skalka.pdf. [24 Jan 2013].

Slovak rectors' conference (2006a). Stanovisko pléna SRK $k$ plagiátorstvu. [Online] Available at: http://old.srk.sk/zaznam/90/ Stanovisko-plena-SRK-k-plagiatorstvu/. [21 Jan 2013]. 
Slovak rectors' conference (2006b). Etický kódex zamestnancov vysokých škôl. [Online] Available at: http://old.srk.sk/zaznam/89/ Eticky-kodex-zamestnancov-vysokych-sk \%C3 \%B41/. [21 Jan 2013].

Staroňová K. (2010). Plagiátorstvo. [Online] Available at: http://www.governance.sk/index.php?id=1731. [24 Jan 2013].

Supuka J. (2008). Akademická etika a plagiátorstvo. [Online] Available at: http://www.polnohospodar.sk/kategoriespravodajstva/24-ponohospodar-1252/476-akademicka-etika-aplagiatorstvo. [21 Jan 2013].

Weber-Wulff, D., Wohnsdorf, G. (2006). Strategies for handling plagiarism. Information-Wissenschaft und Praxis, Vol. 57, Issue 2, March 2006, Pages 90-98. ISSN 14344653

www.indexmundi.com (2012). Internet users. [Online] Available at: http://www.indexmundi.com/slovakia/internetusers.html. [21 Jan 2013]. 